\title{
BUNDA MARIA DALAM PANDANGAN GEREJA KATOLIK DAN \\ KRISTEN DALAM PERSPEKTIF FENOMENOLOGI AGAMA \\ Mata Kuliah: Perbandingan Agama
}

Dosen Pengampu: Dr. Agustinus Wisnu Dewantara, S.S.,M.Hum

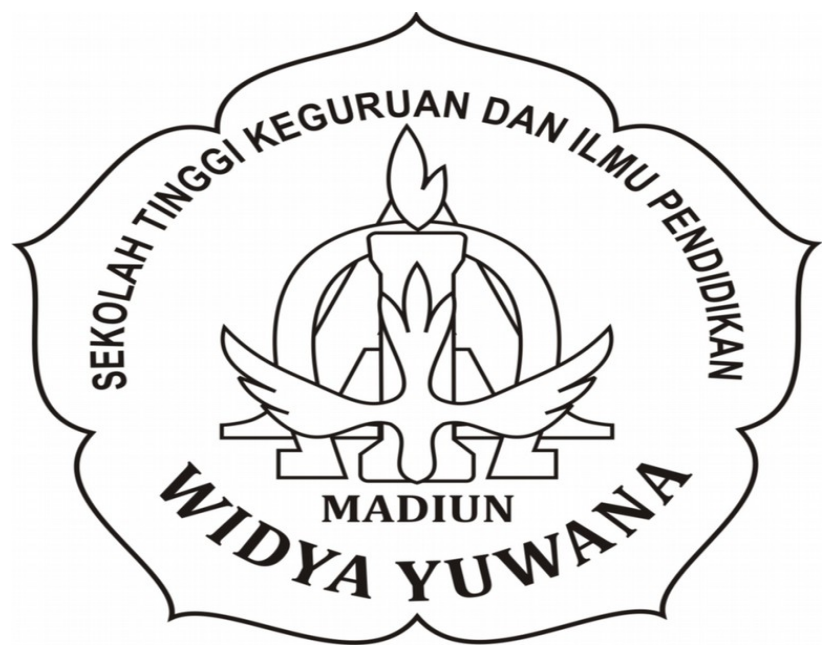

Disusun oleh:

Marsela Trihastuti Hendra

152846

SEKOLAH TINGGI KEGURUAN DAN ILMU PENDIDIKAN WIDYA

YUWANA

MADIUN

2019 


\section{Latar Belakang}

Bunda Maria adalah Bunda Allah dan Bunda Gereja. Ia adalah ibu Yesus, Anak Allah Penyelamat dunia. Kedudukan Bunda Maria dalam Gereja sangat istimewa. Ia adalah orang Kudus terbesar melebihi para kudus lainnya karena peranannya dalam sejarah keselamatan umat manusia. karenanya Ia sangat dihormati. Bunda Maria adalah Bunda Allah karena ia telah melahirkan Yesus Sang Mesias. Karena peranannya begitu besar dalam sejarah keselamatan, maka ia juga menjadi bunda pengantara kita. Melalui dan dalam Maria kita memperoleh kesalamatan dari Allah dalam diri Yesus Kristus Putera Allah, yang menjadi manusia dan dilahirkan Perawan Maria. Peranannya dalam sejarah keselamatan begitu penting. Oleh karena keterpilihannya menjadi seorang Rekan Penebus, Ia dirahmati secara khusus oleh Allah di dalam panggilannya menjadi Bunda Allah (bdk. Luk 1:28).

Allah memilih Bunda Maria untuk menjadi ibu Tuhan (Theotokos); karena ia dipersiapkan secara khusus, sehingga sejak dari dalam kandungan ia tidak berbuat dosa. Ia tetap perawan (dogma 1854). Oleh rahmat dan perlindungan Allah, ia terlindung dari segala noda dosa, ia hidup tanpa cela. Keterpilihan Bunda Maria menjadi Ibu Tuhan ini membuka kembali pintu surge yang telah ditutup karena dosa Hawa. Ia adalah Hawa baru, ibu dari semua yang hidup sebagaimana Kristus adalah Adam baru. Kepasrahannya yang total kepada rencana dan kehendak Allah menjadikan dia sangat berkenan di hadapan Allah. Ia adalah makhluk yang paling sempurna dari semua ciptaan. Bunda Maria adalah model iman yang harus di teladani, iman penuh penyerahan, "Terjadilah padaku menurut kehendak-Mu."(Luk 1:38) Maria adalah contoh dan teladan Gereja yang ulung (LG 53).

\section{Kasus : Menyikapi Viral "Patung Maria Menangis" di Sri Lanka.}

[Serial Kisah Minggu Pagi-9]

Sehari setelah terjadinya pengeboman Paskah Berdarah di Sri Lanka hari Minggu,

21 April 2019, melalui aplikasi Whatsapp, saya menerima foto patung Bunda Maria menangis di Sri Lanka. Tidak ada tanggal dan sumber berita yang menerangkan kapan terjadinya dan di mana patung Maria menangis itu berada. Narasi singkat yang saya terima adalah "Baru kita mengerti mengapa dua hari sebelum pengeboman di Sri Lanka, patung Bunda Maria menangis".

Keterangan pengunggah video itu demikian: 
"Mukjizat patung Bunda Maria Menangis Darah pada Jumat Agung, 19 April 2019 di Gereja Santo Filipus Neri, Katukurunda (Kalutara), Sri Lanka. Gambar-gambar ini dipublikasikan tanggal 20 April 2019." Post Factum Pengeboman di Sri Lanka Publik yang menyaksikan reportase patung Maria menangis segera menghubungkan peristiwa ini dengan pengeboman yang mengguncang Sri Lanka, Minggu, 21 April lalu. Gereja Katolik belum mengeluarkan keputusan resmi mengenai patung Maria menangis di Sri Lanka.

Biasanya Gereja Katolik memang bersikap kritis terhadap dugaan mukjizat dalam bentuk apa pun. Jangankan peristiwa patung menangis, dugaan mukjizat yang dialami seseorang berkat perantaraan orang kudus pun tidak serta-merta dinyatakan sebagai mukjizat dalam waktu singkat oleh otoritas Gereja Katolik. Proses Penyelidikan Resmi oleh Gereja Katolik. Gereja Katolik lazimnya mengadakan penyelidikan resmi yang dilakukan oleh keuskupan setempat. Penyelidikan resmi ini tidak selalu dilaksanakan. Jika uskup setempat menilai tidak perlu diadakan penyelidikan atas peristiwa tertentu, tidak akan ada penyelidikan dari pihak Gereja Katolik.

Jika benar diadakan, Gereja Katolik selalu melibatkan ahli lintas disiplin ilmu.

Dalam kasus patung Maria menangis, Gereja dipastikan meminta keterangan dari pembuat patung, ahli bahan pembuatan patung terkait, tenaga medis, laboratorium klinis, kepolisian serta saksi-saksi terpercaya. Cairan yang menetes dari patung pasti akan diselidiki kandungannya, asalnya (apa dari pengembunan, cat yang mencair, dan seterusnya), dan frekuensi menetesnya.

Tes laboratorium pasti dilakukan untuk mengetahui apakah cairan itu air mata manusia atau darah manusia. Jika proses penyelidikan secara menyeluruh telah dilakukan, Gereja dapat mengumumkan hasilnya dengan narasi ilmiah yang dipadukan dengan sikap iman yang sehat.

Lazimnya, Gereja tidak menyimpulkan bahwa patung menangis air mata atau air mata darah adalah mukjizat yang harus dipercayai umat beriman.

Meski penyelidikan menyimpulkan cairan itu air mata atau darah manusia dan asal-usulnya tak dapat dijelaskan secara ilmiah, Gereja biasanya tidak menyatakan "Ini sungguh mukjizat yang wajib kita percayai". Mengapa? Iman Katolik bersumber bukan pada mukjizat, tetapi pada dua sumber pokok: Alkitab dan Tradisi Suci. Apa yang disampaikan Alkitab dan Tradisi Suci yang diwariskan para rasul sudah cukup. Mukjizat, 
bahkan penampakan Bunda Maria tidak menambah "isi iman Katolik", namun hanya "meneguhkan" saja isi iman Katolik yang sudah kita temukan dalam Alkitab dan Tradisi Suci. Menilai Pewahyuan Pribadi, hal yang sama berlaku untuk pewahyuan-pewahyuan pribadi. Misalnya, seorang Katolik (yang saleh) mengaku mendapat penampakan Yesus atau Bunda Maria dan para kudus.

Pewahyuan pribadi ini "meneguhkan" iman si penerima (tentu si penerima harus secara bijak menilai dengan bimbingan pastor atau pembimbing rohani apakah pewahyuan pribadi itu dari Tuhan atau dari setan yang berpura-pura). Pewahyuan pribadi ini, meskipun demikian dahsyat, sama sekali tidak menambah "isi iman Katolik".

Memang benar, Gereja Katolik akhirnya menjadikan sejumlah pewahyuan pribadi sebagai devosi yang diakui Gereja. Misalnya, penampakan Yesus pada Suster Faustina dari Polandia akhirnya diakui resmi dan dilembagakan dalam "liturgi dan devosi Kerahiman Ilahi".

Akan tetapi, perlu diingat, paham Kerahiman Ilahi bukan suatu hal yang sungguh baru. Kerahiman Ilahi sudah ditemukan dalam Alkitab, misalnya dalam ajaran Yesus mengenai "si anak bungsu pendosa yang diampuni Bapanya".

\section{Sikap yang Tepat Menyikapi Dugaan Mukjizat}

Iman sejati bukan iman yang tergantung dari mukjizat istimewa. Iman sejati tumbuh dari membaca Alkitab, berdoa dengan tekun tiap hari, berderma dengan tulus. Singkat kata, iman sejati tumbuh justru dalam rutinitas olah rohani dan kegiatan sehari-hari, bukan dari peristiwa istimewa yang amat jarang terjadi. Benar bahwa mukjizat itu nyata dan terus terjadi. Akan tetapi, mujkizat itu adalah karunia amat istimewa yang amat langka. Tidak usah terlalu menggantungkan iman pada (dugaan) mukjizat. Tidak perlu menggebu-gebu mencari dan memohon mukjizat. Bukalah mata hati, sadarilah tiap hari Tuhan mengerjakan mukjizat-mukjizat kecil melalui orang-orang dan peristiwa biasa yang kita alami tiap hari.

\section{Pengertian Bunda Maria Dalam Pandangan Gereja Katolik dan Kristen}

\section{$\wp \quad$ Gereja Protestan dan Maria}

dalam perkembangan sejarah Gereja, Gereja Protestan merupakan gerakan yang memisahkan diri dari Gereja Katolik. Perpecahan ini dipelopori oleh beberapa tokoh reformator Protestan, antara lain Martin Luther, John Calvin dan Ulrich Zwingli. Sejak itu, Protestan 
memiliki pemikiran teologi yang cukup berbeda dari Gereja Katolik dan pada akhirnya memberikan pengaruh yang besar dalam kehidupan iman umat Protestan. Bagian ini, akan memaparkan tentang pandnagan bagaimana Gereja Protestan memendang Maria.

Maria adalah salah satu tokoh yang ada dalam Kitab Suci dan peranannya sangat jelas dalam kehidupan Yesus Kristus. Namun, Gereja Protestan memiliki pandangan yang berbeda dalam melihat sosok Bunda Maria. Dalam praktek kehidupan beriman sehari-hari, kita tidak akan menemukan adanya suatu devosi secara khusus oleh umat Protestan kepada Bunda Maria. Untuk itu, kita di sini perlu untuk melihat sesuatu yang melatarbelakanginya.

Pandangan terhadap Maria, iman Katolik memberikan ruang instrumental manusia antara manusia dengan Tuhan. Para orang kudus diakui bahwa mereka memiliki rahmat khusus yang membuat mereka memiliki relasi yang begitu dekat dengan Tuhan. Serupa dengan para orang kudus, Maria mendapat tempat istimewa karena Maria dipilih khusus oleh Allah menjadi ibu dari Tuhan Yesus. Protestan memiliki kesulitan untuk mengakui peran Maria dalam keselamatan Allah, mereka meyakini ketuhanan Yesus tanpa kualifikasi-kualifikasi atau syarat-syarat tertentu. Hal ini dapat di buktikan dengan berbagai kisah dalam Kitab suci. Namun, pandangan kepada Yesus tidak bisa secara otomatis juga menjadi pandangan bagi Maria.

Katolik menyebut Maria sebagai Bunda Allah dan orang Kristen pertama; untuk dikasihi dan juga menghatar kita kepada Cinta Kristus, untuk di tiru dan juga memimpin pada keserupaan dengan Kristus; disebut berbahagia dan diberkati di antara wanita dan juga menjadi figure bagi kita untuk memuji Allah. Namun, dari itu smeua, umat Protestan meyakini bahwa Maria tidak diminta secara khusus sebagai perantara manusia dengan Tuhan atau dinobatkan sebagai perantara kita dengan Kristus. Dan banyak orang mengira bahwa orang Katolik menyembah Maria dan berdoa kepada Maria. Hal ini mungkin disebabkan karena banyak orang melihat orang Katolik berdoa di depan patung Bunda Maria dan berdoa Rosario.

Namun, perlu ditegaskan kembali bahwa orang Katolik sama sekali "tidak menyembah" Maria, tetapi menghormati Maria. Ini dua istilah yang kelihatannya mirip tetapi maknanya sangatlah berbeda. Penghormatan orang Katolik terhadap Maria tentu tidak muncul begitu saja. Penghormatan seperti ini jelas ada alasannya, yaitu karena Maria adalah ibu Tuhan sebagaimana dikatakan Elisabet (bdk. Luk 1:43). Dari sini dapat kita ambil contoh misalnya ibu kita sendiri, jangankan ibu Tuhan, ibu kita sendiri saja kita hargai dan hormati.

\section{Pandangan Katolik Tentang Maria}


Dalam Perjanjian Baru, yakni surat-surat Paulus tidak memuat sesuatu apa pun tentang Maria. Dalam suarat Galatia (4:4) hanyalah disebutkan bahwa Yesus itu lahir dari seoranng wanita. Maksudnya : Yesus itu betul menjadi mnausia! Penghormatan kepada Maria menjadi makin jelas dalam injil Lukas, yang mungkin juga ditulis pada sekitar tahun 80. Injil Lukas menegaskan bahwa Maria mendapat pewahyuan ilahi dari Malaikat Gabriel, ketika ia sedang bertunangan dengan Yusuf. Utusan Allah itu menyatakan bahwa Allah menyertai Maria, memberinya kasih karunia, dna menaunginya dengan kuasa-Nya, sehingga ia mengandung Juru Selamat dengan kekuatan Roh Kudus (Luk 1). Setelah memahami maksud dari pewartaan itu, dengan penuh kerendahan dan keikhlasan hati, Maria menerima perutusan luhur itu (Luk 1). Dalam perjumpaannya dengan Maria, Elisabet, ibu dari Yohanes Pemandi, menyebut Maria sebagai "ibu Tuhan" dan "terberkati" di antara semua wanita" (Luk 1). Menanggapi hal itu, Maria selalu bersyukur dan memuji Allah (Luk 1). Selanjutnya, Maria selalu berusaha memahami kehendak dan rencana Allah dengan :menyimpan dalam hati” segala perkara (Luk 2). Maria sabar menghadapi "misteri ilahi”.

Sejak abad ke 4, berkembanglah penghormatan yang kuat kepada Maria. Karena Maria bukan seorang martir, tampaknya sampai abad ke-3 belum muncul penghormatan yang kuat kepadanya. Barulah sejak abad ke-4, ketika Kristen diakui sebagai agama yang sah, dan karenanya tidak banyak lagi orang mati sebagai martir, penghormatan kepada Maria mulai berkembang. Dalam liturgy maupun devosi yang berkembang bagi ibu Tuhan Yesus itu, Maria dipandang bukan lagi semata-mata sebagai seorang "tokoh masa lalu", melainkan "tpkoh masa kini”, yang doa-doanya dan perhatiannya selalu bisa diharapkan. Ia selalu bisa dihubungi oleh umat yang membutuhkan pertolongannya dalam berbagai hal, termasuk perihal kebutuhankebutuhan hidup sehari-hari. Sementara dalam liturgy, doa-doa resmi Gereja tetap terarah kepada Allah; dalam devosi umat, doa-doa dari umat biasa juga terarah langsung kepada Maria. Sementara, liturgy kepada Maria cenderung formal dan monoton, devosi umat kepada Maria lebih kreatif dan efektif. Devosi kepada Maria terbukti mampu membantu umat lebih menghayati dan "merasakan" kasih Allah.

Para bapa Gereja menyebut Bunda Maria sebagai bunda suci seutuhnya, tidak terkena cemar dosa mana pun. Mereka juga meyakini bahwa Maria tidak secara pasif belaka digunakan oleh Allah, melainkan bekerja sama dengan-Nya dalam iman serta ketaatan. Mereka mengakui 
bahwa " ikatan yang disebabkan oleh ketidaktaatan Hawa telah dilepas oleh karena ketaatan Maria" (LG 56).

Persatuan Maria dengan putranya dalam karya penyelamatan terungkap sejak saat Kristus berada dalam kandungannya. Persatuan itu kemudian tampak pada kelahiran bayi Yesus, ketika Maria memperkenalkan Putranya kepada para gembala dan orang-orang majus. Persatuan itu juga tampak ketika Kanak-Kanak Yesus dipersembahkan dalam Bait Allah (LG 57). Dalam hidup Tuhan Yesus di muka umum, tampillah Maria dengan penuh makna, ketika pada pesta pernikahan di Kana ia tergerak oleh belas kasihan, lalu mendorong Putranya untuk mengerjakan mukjizat-Nya yang pertama. Dalam pewartaan Putranya, Maria menerima sabda-Nay. Dan akhirnya, menjelang wafat Putranya, ia dikaruniakan kepada murid-Nya menjadi ibu bagi murid itu (LG 58). Sesudah Tuhan Yesus naik ke surge, Maria tetap berada di tengah-tengah para rasulNya. Dan akhirnya, setelah menyelesaikan perjalanan hidupnya di dunia, Maria telah diangkat ke surge beserta badan dan jiwanya (LG 59).

Gereja mengajarkan bahwa dunia hanya memiliki satu Pengantara Keselamatan, yakni Tuhan Yesus Kristus. Namun, Gereja sekaligus mengajarkan bahwa penghormatan terhadap Maria sedikit pun tidak menyuramkan martabat Kristus sebagai satu-satunya Pengantara Keselamatan, melainkan justru menguatkannya (LG 60). Dengan mengandung, melahirkan, membesarkan Putranya, dan ikut menderita dengan-Nya, Maria telah bekerjasama secara istimewa dengan Juru Selamat itu dalam karya penyelamatan dunia (LG 61). Setelah diangkat ke surge , Maria tidak kehilangan peran. Ia terus-menerus memperolehkan bagi kita karunia-karunia yang mneghantar menuju keselamatan. Oleh karena itu, Gereja menganjurkan kaum beriman untuk memohon perlindungan dari Maria, agar Maria berkenan mendukung usaha mereka untuk bersatu dengan Sang Juru Selamat (LG 62).

\section{Dalam perspektif fenomenologi agama}

Fenomenologi agama adalah dalam arti klasik tidak menonjolkan usaha penetapan dan penentuan ruang lingkung historis dan sosiologis, yang menjadi tempat munculnya fenomenafenomena religious. Fenomenologi ini yang tentu berlandaskan pada pemahaman fenomen religious "sebagaimana fenomen-fenomen itu tampak pada kita". Bila kita berhadapan dengan obyek tertentu hendak berkata-kata tentangnya, kita membiarkan obyek itu bersama gejalagejalanya berbicara kepada kita. Kita hanya meluiskan bagaimana obyek itu tampil pada kita bagaimana adanya. Dan kita sebagai umat ciptaan Tuhan berhak menentukan pilihan kita 
masing-masing untuk memeluk agama yang kita percaya dan kita yakini dan tanpa paksaan dari siapa pun.

\section{Penutup}

Dari Gereja Purba, kehadiran Bunda Maria dalam peziarahan iman merupakan suatu kehadiran yang tidak dapat diabaikan. Kehadiran itu telah diakui sebagai inti iman kristiani. Sebelum reformasi Protestan, umat mempersembahkan kepada "Ibu Yesus" penghormatan dalam aneka bentuk, doa, permohonan, perlindungan, dan memandangnya sebagai teladan ideal, citra seorang beriman yang tulen dan injili. Dalam Gereja, akan terus bergema karunia Tuhan Yesus

"Inilah anakmu; inilah Ibumu". Dalam uraian diatas dimana kita semua bagaimana cara kita mewujudkan diri kita sendiri untuk menetukan pilihan dan meyakini kepercayaan masing-masing tanpa harus memaksakan dan menuruti kehendak hati orang lain. 


\section{DAFTAR PUSTAKA}

Agustinus Wisnu Dewantara. 2019. Diktat Ilmu Perbandingan Agama Hal 109. Madiun.

Ardijanto, Don Bosco Karnan, and Ignatius Damar Putra. "DEVOSI KEPADA BUNDA MARIA BERDASARKAN DOKUMEN MARIALIS CULTUS DAN PELAKSANAANNYA DI PAROKI MATER DEI MADIUN." JPAK: Jurnal Pendidikan Agama Katolik 13.7 (2015): 43-54.

Hadiwardoyo, Purwa.2017. Pandangan Katolik Tentang Maria. Yogyakarta: Kanisius.

https://www.kompasiana.com/bobby18864/5cc20e0595760e74127e2676/menyikapi-viral-

patung-maria-menangis-di-sri-lanka?page=all

Sabato, Salvatore. 2006. Inilah Ibu ku Sebuah Ringkasan Mariologi. Yogyakarta: Kanisisus. 